\title{
Cognitive impairment after sudden cardiac arrest
}

\author{
Magdalena Jaszke-Psonka ${ }^{1}$, Magdalena Piegza ${ }^{2}$, Piotr Ścisło ${ }^{3}$, Robert Pudlo², Jacek Piegza ${ }^{4}$, \\ Karina Badura-Brzoza ${ }^{2}$, Aleksandra Leksowska², Robert T. Hese ${ }^{3}$, Piotr W. Gorczyca ${ }^{2}$ \\ ${ }^{1}$ Mental Health Center - Phoenix, Katowice, Poland \\ 2Department and Clinic of Psychiatry in Tarnowskie Góry, SMDZ in Zabrze, Medical University of Silesia in \\ Katowice, Poland \\ ${ }^{3}$ Department of Psychiatry, Multi-District Hospital, Tarnowskie Góry, Poland \\ ${ }_{4}^{4}{ }^{\text {rd }}$ Department of Cardiology, Silesian Centre for Heart Diseases, Zabrze, Poland \\ Kardiochirurgia i Torakochirurgia Polska 2016; 13 (4): 393-398
}

\begin{abstract}
Aim: To evaluate the incidence and severity of the impairment of selected cognitive functions in patients after sudden cardiac arrest (SCA) in comparison to patients after myocardial infarction without SCA and healthy subjects and to analyze the influence of sociodemographic and clinical parameters and the duration of cardiac arrest on the presence and severity of the described disorders.

Material and methods: The study group comprised 30 cardiac arrest survivors, the reference group comprised 31 survivors of myocardial infarction without cardiac arrest, and the control group comprised 30 healthy subjects. The Mini-Mental State Examination (MMSE), the Digit Span test from the Wechsler Adult Intelligence Scale, Lauretta Bender's Visual-Motor Gestalt Test, and the Benton Visual Retention Test (BVRT) were used to assess the presence of cognitive impairment. An original questionnaire developed by the author was used for overall mental state assessment.

Results: The Bender test demonstrated a significant difference in the presence and severity of visual-motor skills between the study group and the control group, while BVRT and MMSE revealed increased incidence of cognitive impairment in the study group. The Bender and BVRT (D/D)/SS (version D, method D, scaled score) scales indicated cognitive impairment in $53.3 \%$ of these patients, while the BVRT (C/A)/SS test indicated cognitive impairment in $40 \%$. For the reference group, the values were $32.3 \%$ and $12.9 \%$, respectively. No correlation was found between the severity of cognitive impairment and the duration of cardiac arrest.

Conclusions: Impairment of visual-motor skills, short-term visual memory, concentration, and visual-motor coordination occurs much more frequently and is more severe in individuals after SCA than in healthy individuals. Impairment of memory trace storage and recall after delay occurs more frequently in patients after SCA than in patients after myocardial infarction without cardiac arrest and in healthy individuals. SCA duration did not have any influence on the severity of the described disorders. Key words: cognitive function, cardiac arrest, coronary heart disease.
\end{abstract}

\section{Streszczenie}

Cel: Ocena częstości występowania i nasilenia zaburzeń wybranych funkcji poznawczych u pacjentów po nagłym zatrzymaniu krążenia (NZK) w odniesieniu do osób po przebytym zawale mięśnia sercowego bez NZK i osób zdrowych oraz analiza wpływu niektórych parametrów socjodemograficznych i klinicznych oraz czasu trwania NZK na obecność i nasilenie opisywanych zaburzeń poznawczych.

Materiat i metody: Grupę badaną utworzyło 30 osób po NZK, grupę odniesienia - 31 osób po zawale serca bez NZK, a grupę kontrolną - 30 osób zdrowych. Do oceny obecności zaburzeń wybranych funkcji poznawczych użyto Krótkiej skali oceny stanu psychicznego (MMSE), Testu powtarzania cyfr ze Skali inteligencji Wechslera dla dorosłych, Testu zdolności wzrokowo-motorycznych Lauretty Bender oraz Testu pamięci wzrokowej Bentona (BVRT). Oryginalnie opracowany kwestionariusz posłużył do ogólnej oceny stanu psychicznego.

Wyniki: W teście Lauretty Bender stwierdzono istotną różnicę w występowaniu i nasileniu zaburzeń zdolności wzrokowo-motorycznych w grupie badanej w stosunku do grupy kontrolnej, a w teście BVRT i MMSE - częstsze występowanie zaburzeń poznawczych w grupie badanej. U tych osób zaburzenia poznawcze mierzone skalami Bender i BVRT (D/D)/WP występowały u 53,3\% badanych, a testem BVRT (C/A)/WP - u 40\% osób. Dla grupy odniesienia wartości te wynosity odpowiednio 32,3\% i $12,9 \%$. Nie wykazano zależności nasilenia zaburzeń poznawczych od czasu trwania NZK.

Wnioski: Zaburzenia zdolności wzrokowo-motorycznych, krótkotrwałej pamięci wzrokowej, koncentracji oraz koordynacji wzrokowo-ruchowej u osób po przebytym NZK występują znacznie częściej i są bardziej nasilone niż u osób zdrowych. Zaburzenia zdolności przechowywania śladu pamięciowego i odtwarzania go po odroczeniu występują $u$ chorych po przebytym NZK częściej niż u pacjentów po przebytym zawale mięśnia sercowego bez NZK i u osób zdrowych. Czas trwania NZK nie miał wpływu na nasilenie opisywanych zaburzeń.

Słowa kluczowe: funkcje poznawcze, zatrzymanie krążenia, choroba wieńcowa.

Address for correspondence: Dr Piotr Ścisło, Department of Psychiatry, Multi-District Hospital, 49 Pyskowicka St, 42-600 Tarnowskie Góry phone: +48 601481 178, e-mail: piosci1@poczta.onet.pl

Received: 4.09.2016, accepted: 17.11.2016. 


\section{Introduction}

Brain tissue ischemia and hypoxia associated with sudden cardiac arrest (SCA) trigger a series of detrimental biomechanical mechanisms [1, 2]. The interruption of blood supply to the brain that occurs during SCA may result in cognitive deterioration. According to the literature, the longer the SCA episode, the higher the risk of cognitive impairment, especially of short-term memory as well as immediate and delayed recall [3-5]. Attention deficits and executive function disorders are second in terms of frequency [6].

When searching for factors affecting the occurrence of these disorders, Sauve et al. discovered that the duration of coma after resuscitation (time-to-awakening) positively correlates with the presence of cognitive deficits [6, 7]. Another study showed that cardiopulmonary resuscitation (CPR) has a positive influence on cognitive function regardless of its initiation time, which was explained by the patient-specific sensitivity of nerve tissue to hypoxia and different CPR quality [6]. The available methods of preventing ischemic brain tissue damage provide some hope for improving the functioning of patients $[8,9]$, but the effectiveness of such methods varies $[8,10]$. The etiological factors of cognitive deterioration mainly include hypertension, atherosclerosis, peripheral artery diseases, myocardial infarction, and cardiac arrest. In the course of ischemic heart disease, cognitive impairment mainly involves the deterioration of attentional selectivity, visual memory, understanding by analogy, and psychomotor speed [11].

\section{Aim}

The aim of the study was to assess the incidence of the impairment of certain cognitive functions in patients after SCA in relation to individuals who experienced myocardial infarction without SCA and healthy individuals as well as to analyze the influence of certain sociodemographic and clinical factors and SCA duration on the occurrence and severity of the described cognitive disorders.

\section{Material and methods}

Patients after SCA which occurred at least 1 month and less than 6 months before the study were examined at the "Repty" Upper Silesian Rehabilitation Center, an independent public health care institution. The reference group was composed of individuals after myocardial infarction without cardiac arrest with the same time criteria. The control group included healthy individuals appropriately selected with respect to sex and age, without any significant mental or somatic disorders. Individuals with mild hypertension without organ lesions as well as individuals with stable coronary artery disease with no previous myocardial infarction were also allocated to the control group. The influence of the following factors on the risk of cognitive impairment was analyzed: sex, age, marital status, education, treatment with medications potentially affecting mental state, duration of SCA (due to the difficulties in establishing the precise duration of SCA episodes, the patients were divided into two general categories: patients in whom the SCA episode was shorter than 3 min and patients in whom the SCA was longer than $3 \mathrm{~min}$ ), invasive cardiac treatment, presence of ischemic heart disease, hypertension, and other diseases. The exclusion criteria were the following: withdrawal of consent for participation in the study, mental disorders diagnosed before the SCA episode, currently present stressors of high intensity in the patients' subjective assessment, addiction to drugs and/or alcohol, moderate or severe dementia, and age over 65 years. The following standardized clinical research tools were used for assessing cognitive function: the Mini-Mental State Examination (MMSE), a subscale of Wechsler Adult Intelligence Scale - the Digit Span test, Lauretta Bender's Visual-Motor Gestalt Test, and the Benton Visual Retention Test (BVRT). An original questionnaire developed by the author was used for overall mental state assessment. When analyzing the parameters for BVRT, two versions of the scale were used $-C$ and $D$. In version $C$ the most common method was applied - method A (C/A), which consists in immediately reproducing a pattern that was previously displayed for $10 \mathrm{~s}$. In version D method D was employed (D/D), which includes a time delay between the process of viewing and reproducing the pattern [12]. The Digit Span test measures memory and resistance to distractors interfering with the concentration of awareness. It is one of the subtests of the Wechsler Intelligence Scale WAIS-R(PI) and can be used independently due to its standardization. The Bender test measures a series of functions depending on the efficient operation of different areas of the brain: the ability to see and recognize patterns, to understand relations between elements of the patterns and to recall them, graphomotor skills, and the integration of those abilities. The MMSE scale was used as a screening tool to detect dementia syndromes. The Bioethical Committee of the Medical University of Silesia in Katowice granted its approval to conduct the study (NN-013-216/03).

\section{Statistical analysis}

The study employed the following statistical tests: the Shapiro-Wilk test, Kruskal-Wallis test, Mann-Whitney $U$ test, $\chi^{2}$ test with Yates' correction, Fisher's exact test, and Spearman's rank correlation coefficient. The level of $p \leq 0.05$ was considered statistically significant.

\section{Results \\ Characteristics of the study group}

The SCA group was composed of 30 patients; their demographic characteristics are presented in Table I. Five $(16.67 \%)$ patients were taking medications that affect the mental state (in the majority of cases, these were $\beta$-adrenolytics and calcium channel antagonists) and a few individuals were taking antihistamine medications and corticosteroids. There were 10 (33.33\%) individuals who underwent percutaneous transluminal coronary angioplasty (PTCA), in most cases accompanied by stent implantation; 
Tab. I. Patient group characteristics

\begin{tabular}{|c|c|c|c|c|c|c|c|}
\hline \multirow[t]{2}{*}{ Group } & \multirow[t]{2}{*}{$N$} & \multirow[t]{2}{*}{ Women } & \multirow[t]{2}{*}{ Men } & \multirow[t]{2}{*}{ Age $x \pm S D$} & \multicolumn{3}{|c|}{ Education } \\
\hline & & & & & Primary/vocational & Secondary & Higher \\
\hline Study group & 30 & $8(26.7 \%)$ & $22(73.3 \%)$ & $52.9 \pm 8.8$ & $12(40.0 \%)$ & $13(43.3 \%)$ & $5(16.7 \%)$ \\
\hline Controls & 30 & $8(26.7 \%)$ & $22(73.3 \%)$ & $52.4 \pm 6.5$ & $11(36.7 \%)$ & $13(43.3 \%)$ & $6(20.0 \%)$ \\
\hline Reference group & 31 & $11(35.5 \%)$ & $20(64.5 \%)$ & $55.3 \pm 7.0$ & $13(41.9 \%)$ & $13(41.9 \%)$ & $5(16.1 \%)$ \\
\hline Group comparison & & \multicolumn{2}{|c|}{$\chi^{2}$ test: NS $(p=0.68)$} & Kruskal-Wallis test NS $(p=0.33)$ & \multicolumn{3}{|c|}{$\chi^{2}$ test: NS $(p=0.88)$} \\
\hline
\end{tabular}

26 (86.67\%) patients suffered from coronary artery disease. The most common comorbidity in the group was hypertension, which was present in 15 (50\%) patients. Other diseases (most frequently diabetes, COPD, allergies, and stomach ulcers) were found in $43.33 \%$ of patients. The causes of SCA in all the studied patients were cardiovascular. In most patients the cardiac arrest was accompanied by myocardial infarction; in three individuals it was associated with myocarditis, and in two it occurred as a result of atrioventricular conduction abnormalities. In three patients the SCA episodes took place during cardiac surgery.

\section{Selected sociodemographic factors}

No statistically significant differences were found between the groups with regard to age, sex, education, marital status, and treatment with medications that may influence mental state. No significant differences were revealed between the number of patients undergoing invasive treatment in the study group and the reference group. Hypertension was present significantly more frequently in the study group and the reference group than in the control group.

\section{Cognitive functions}

In order to simplify the analysis, only scaled scores (SS) of the BVRT and Digit Span test were studied. In the Bender test, a statistically significant difference was revealed in the incidence and severity of visual-motor impairment in the study group in comparison to the control group (Fig. 1), while the BVRT test (version C) demonstrated that cognitive impairment in the study group occurred significantly

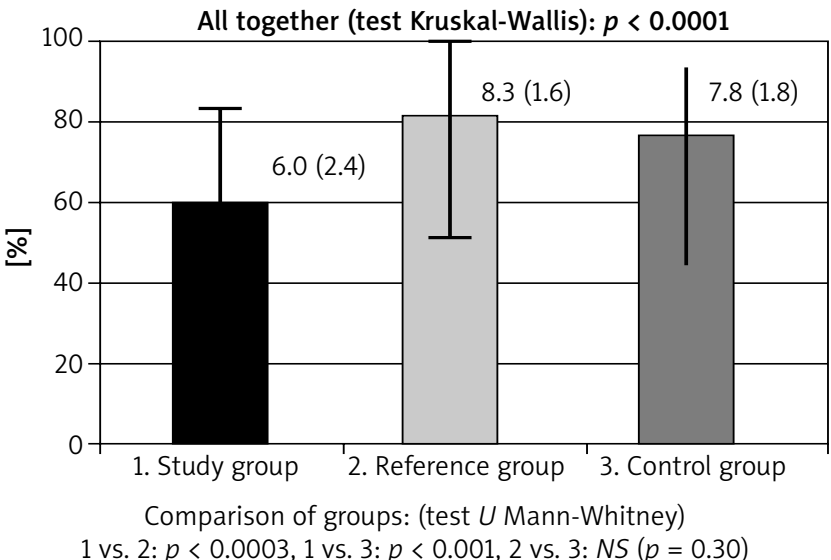

Fig. 2. Mean values and standard deviations on the BVRT (C/A)/NCR (number of correct reproductions) scale in each group
All together (test Kruskal-Wallis): $p<0.0001$

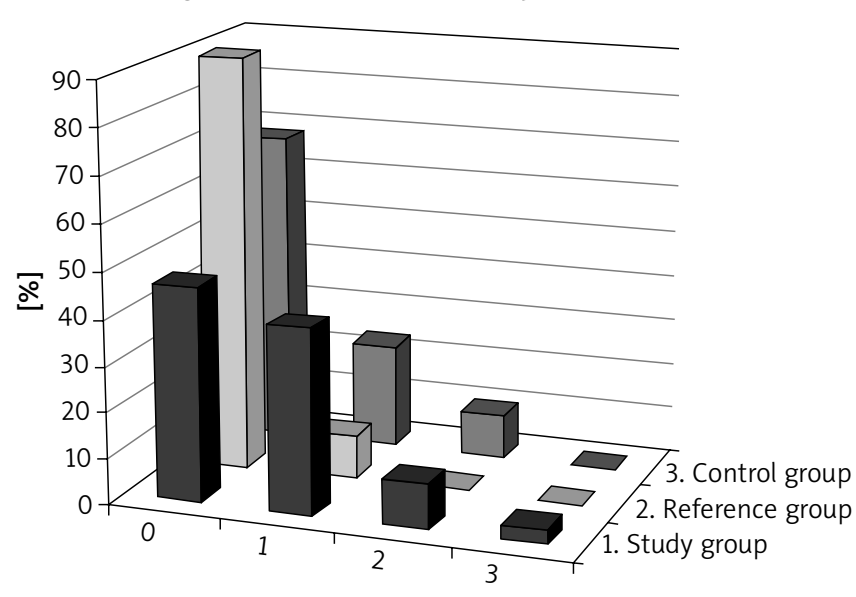

Scale value Bender

Comparison of groups: (test $U$ Mann-Whitney)

1 vs. $2: p<0.003,1$ vs. $3:$ NS ( $p=0.17), 2$ vs. $3:$ NS ( $p=0.12)$

$\square$ 1. Study group $\square 2$. Reference group $\square 3$. Control group

Fig. 1. Bender test scores in each group ( 0 - no disorder, $1-$ low severity, 2 - moderate severity, 3 - significant severity)

more frequently in comparison to the remaining groups. For version $D$, disorders were found more frequently in the study group and the reference group in comparison to the control group (Figs. 2-7). No statistically significant differences were found between the groups in terms of the Digit Span test results, while cognitive impairment on the MMSE scale was significantly more frequent in the study group as compared to the control group (Fig. 8). No statisti-

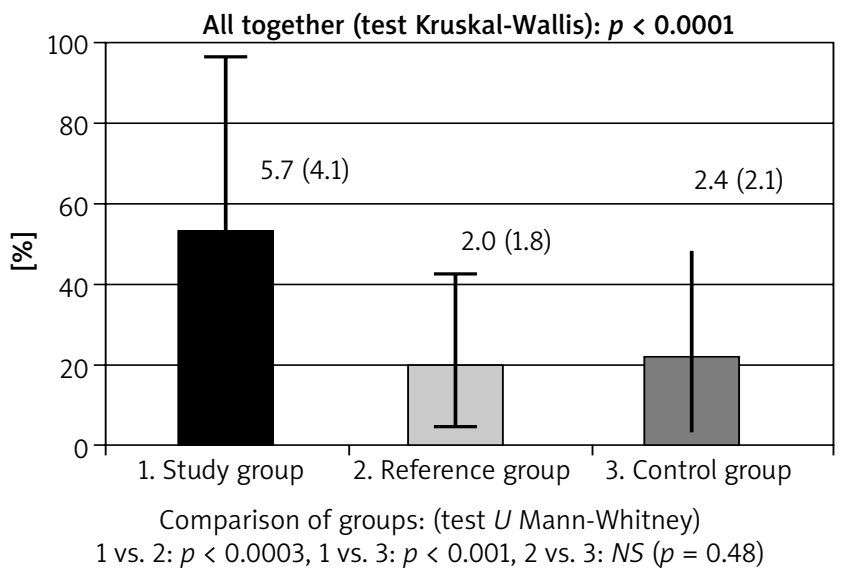

Fig. 3. Mean values and standard deviations on the BVRT (C/A)/NM (number of mistakes) scale in each group 


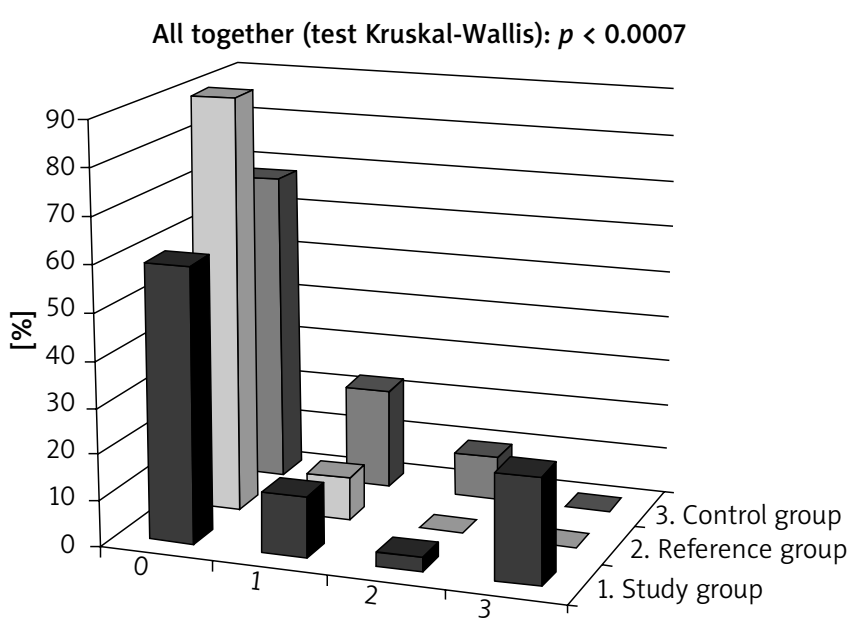

Scale value Bender

Comparison of groups: (test $U$ Mann-Whitney)

1 vs. $2: p<0.02,1$ vs. $3: p<0.05,2$ vs. $3:$ NS $(p=0.54)$

$\square 1$ Study group $\square 2$. Reference group $\square 3$. Control group

Fig. 4. Values on the BVRT (C/A)/SS scale in each group ( 0 - no disorder, 1 - low severity, 2 - moderate severity, 3 - significant severity)

All together (test Kruskal-Wallis): $p<0.0001$

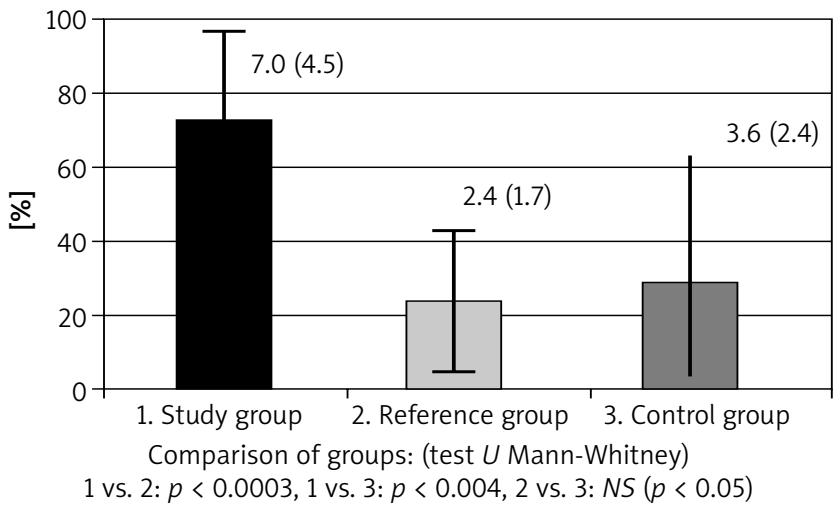

Fig. 6. Mean values and standard deviations on the BVRT (D/D)/ NM (number of mistakes) scale in each group

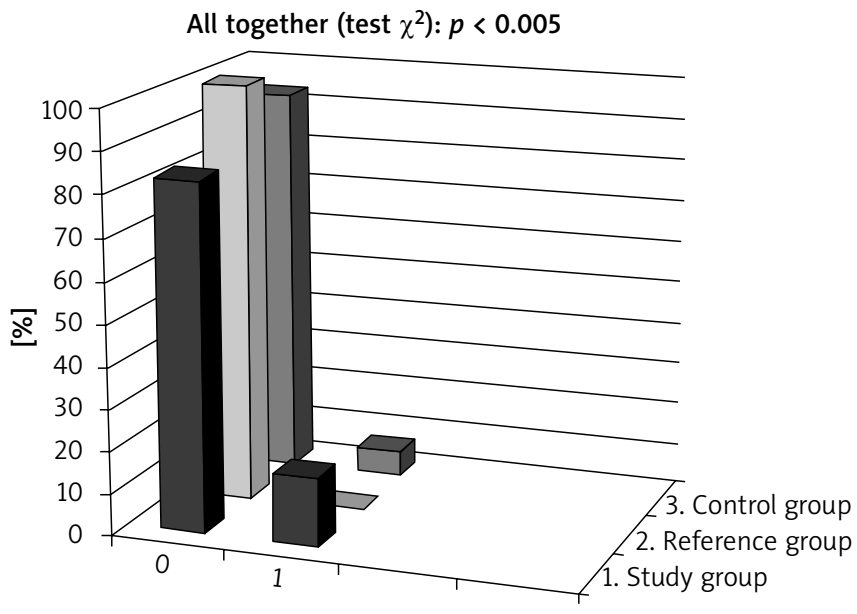

Values MMSE 1 = no dementia, 2 = light degreee of dementia Comparison of groups: (test Fishera)

1 vs. $2: p<0.03,1$ vs. $3: p=0.20,2$ vs. $3:$ NS $(p<0.22)$

$\square$ 1. Study group $\square 2$. Reference group $\square 3$. Control group

Fig. 8. Incidence of dementia in each group according to the MMSE

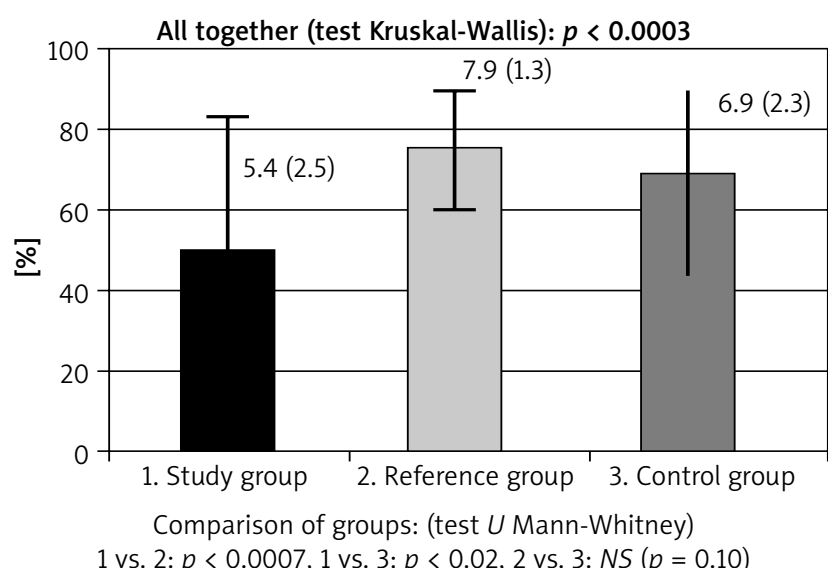

Fig. 5. Mean values and standard deviations on the BVRT (D/D)/ NCR (number of correct reproductions) scale in each group

All together (test Kruskal-Wallis): $p<0.0001$

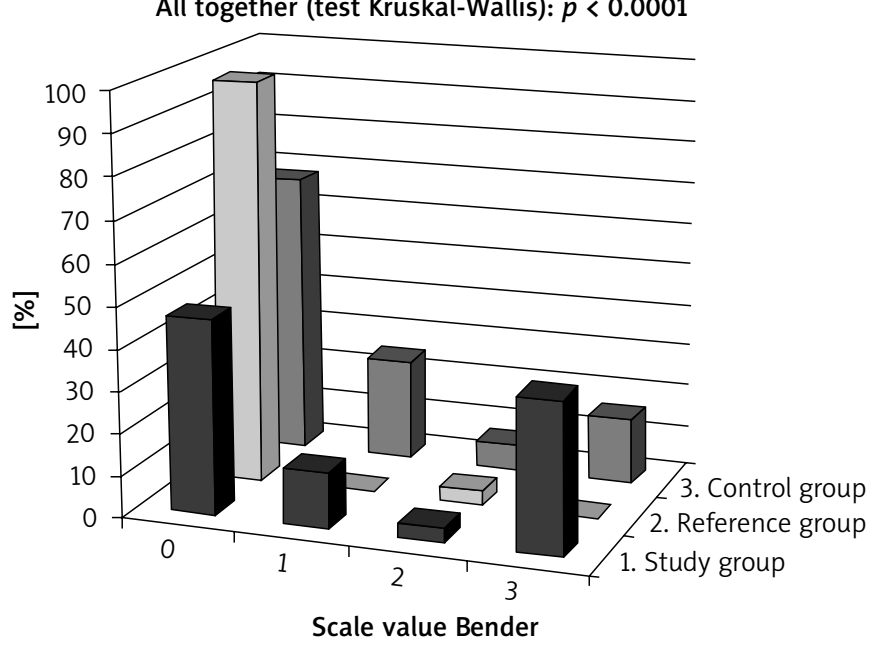

Comparison of groups: (test $U$ Mann-Whitney)

1 vs. $2: p<0.001,1$ vs. $3:$ NS ( $p=0.11), 2$ vs. $3:$ NS $(p<0.05)$

$\square$ 1. Study group $\square 2$. Reference group $\square 3$. Control group

Fig. 7. Values on the BVRT (D/D)/SS scale in each group ( 0 - no disorder, 1 - low severity, 2 - moderate severity, 3 - significant severity)

cally significant differences were found between the study group and the reference group with regard to the Bender test, MMSE, and version C of the BVRT test. The percentage of patients with cognitive impairment from each group according to individual scales is presented in Table II.

It was discovered that the values on the Bender scale were higher in older individuals, and the tendency for lower values in the Digit Span test increased together with higher levels of education (Tab. III). No correlation was found between the scale scores and marital status, taking medications, invasive treatment, presence of ischemic heart disease, hypertension, or other diseases.

There was a visible, but statistically insignificant dependence of the Bender test results on SCA duration.

\section{Discussion}

Standardized methods of neuropsychological diagnostics were used to evaluate the severity and incidence of 
Tab. II. Percentage of patients in each group with diagnosed function impairment according to the scales

\begin{tabular}{lccc} 
Scale & Study group & Controls & Reference group \\
Bender & $16(53.3 \%)$ & $3(10.0 \%)$ & $10(32.3 \%)$ \\
\hline BVRT (C/A)/SS & $12(40.0 \%)$ & $1(3.3 \%)$ & $4(12.9 \%)$ \\
\hline BVRT (D/D)/SS & $16(53.3 \%)$ & $1(3.3 \%)$ & $10(32.3 \%)$ \\
\hline Digit Span SS & $9(30.0 \%)$ & $4(13.3 \%)$ & $6(19.4 \%)$ \\
\hline Cochran's Q test & $p<0.05$ & NS $(p=0.36)$ & $p<0.005$ \\
\hline
\end{tabular}

BVRT - Benton Visual Retention Test, C/A - version C, method A, D/D - version D, method D, SS - scaled score.

the specified cognitive disorders in the study, control, and reference groups and to assess the extent of cognitive impairment [13-15]. The following functions were studied: visual-motor skills, short-term visual memory, awareness concentration and visual-motor coordination, memory trace storage and recall after delay, as well as short-term auditory-categorical memory. Considering the known relationship between the duration of central nervous system hypoxia and the degree of brain tissue damage, the severity of organic cognitive impairment in patients after SCA should depend on the duration of the episode. This relationship was not confirmed; however, the higher incidence of cognitive impairment that we found in patients after SCA was in line with the results obtained by other centers. Roine diagnosed cognitive impairment in $60 \%$ of patients examined 3 months after the occurrence of SCA, while Sauve demonstrated the impairment of some cognitive functions in $29 \%$ of individuals 6 months after the cardiac arrest [7, 16, 17]. Due to methodological differences, comparative analysis is difficult [14]. Most authors focus on the assessment of memory disorders, even though the results of some studies suggest concomitant impairments of numerous cognitive functions caused by diffuse CNS damage after SCA [18]. According to Drysdale et al., areas of weaker blood flow, such as the hippocampus, are especially susceptible to damage [19]. As a result, there is significant risk of memory impairment in SCA survivors. Drysdale points to the fact that memory impairment occurs in approximately $1 / 3$ of patients examined approximately 8 months after SCA. Pusswald et al. describe chronic memory, orientation, and attention impairments in individuals after SCA [20]. In our study, patients after SCA exhibited reduced intellectual capacity, mild-to-moderate memory impairment, and amnestic syndromes. Lim et al. also emphasize the co-occurrence of visual-motor disorders with memory impairment. No isolated amnesia was observed among the patients studied by this team [18]. After studying a group of 68 patients 3 months after SCA, Roine found cognitive disorders in approximately $60 \%$. At 12 months after the SCA episode, $48 \%$ of the 54 patients remaining alive still exhibited moderate-to-severe impairment of cognitive functions [16]. Sauve et al. also noted the occurrence of cognitive impairment in 29\% of patients 6 months after SCA $[7,17]$. Furthermore, Sunnerhagen et al. point to a reduction in cognitive function and activity in individuals studied approximately 25 months after an SCA episode
Tab. III. Results of Spearman's rank correlation coefficient only for those factors characterizing the study group for which statistical significance was achieved with the results on the scales

\begin{tabular}{lcccc} 
Factor & $\begin{array}{c}\text { Bender } \\
\text { scale }\end{array}$ & $\begin{array}{c}\text { BVRT SS/CA } \\
\text { scale }\end{array}$ & $\begin{array}{c}\text { BVRT SS/DD } \\
\text { scale }\end{array}$ & $\begin{array}{c}\text { Digit Span } \\
\text { test SS }\end{array}$ \\
Age & $\begin{array}{c}R=0.38 \\
p<0.04^{\mathrm{a}}\end{array}$ & $\begin{array}{c}R=-18 \\
\text { NS } \\
(p=0.33)\end{array}$ & $\begin{array}{c}R=-0.26 \\
\text { NS } \\
(p=0.16)\end{array}$ & $\begin{array}{c}R=0.24 \\
\text { NS } \\
(p=0.19)\end{array}$ \\
\hline \multirow{3}{*}{ Education } & $\begin{array}{c}R=-0.19 \\
\text { NS } \\
(p=0.30)\end{array}$ & $\begin{array}{c}R=-0.13 \\
\text { NS } \\
(p=0.49)\end{array}$ & $\begin{array}{c}R=-0.09 \\
\text { NS } \\
(p=0.65)\end{array}$ & $\begin{array}{c}R=-0.49 \\
p<0.01^{b}\end{array}$ \\
\hline
\end{tabular}

$R$-correlation coefficient, $p$ - statistical significance, ahigher scale values with age, blower scale values with higher levels of education, SS - scaled score.

[21]. Weigl et al. studied the presence of cognitive disorders in patients who experienced short-term SCA during cardiac procedures. Interestingly, they point out that even a short episode of brain hypoxia may lead to the occurrence of cognitive disorders [5]. Polanowska et al. revealed that from $100 \%$ (early after SCA) to 57\% (12 months after SCA) of study participants exhibited cognitive impairment co-occurring mainly with neurological symptoms. Memory disorders proved to be the most common and significant problem. Executive, attention, language (mainly anomia), and visual-spatial deficits were less severe. Even though the disorders were characterized by a tendency to subside with time, more than $50 \%$ of patients continued to exhibit certain deficits and, in $30 \%$ of cases, significant disability 12 months after SCA. The results of examinations conducted in the third month after SCA showed that 76\% of the patients who were able to cooperate required therapy - mainly neuropsychological rehabilitation [22]. In the present study, we observed a tendency for individuals with higher education levels to achieve lower values in the Digit Span test. This may be explained by the fact that longer periods of education translate into longer training of cognitive capacity involved in the process of learning, including the functions analyzed in this study. A higher number of years devoted to education may also directly point to the ambition of such individuals to expand their theoretical knowledge and practical skills even after completing formal education. As indicated by data obtained through imaging examinations, the brain structure continues to change even in individuals over 50 years of age, while the study of cognitive functions indicates that the brain maintains its ability to develop crystallized intelligence even at old age. In light of the results obtained by the authors, the level of involvement in intellectual activities, measured by years of education, can be considered a protective factor reducing the consequences of disruptions in brain activity.

We also used the described research material to assess the presence of symptoms of depression and anxiety or symptoms of post-traumatic stress disorder. The data obtained from this research served as a basis for other publications. It is, therefore, important to consider the possible influence of emotional disorders on the results of tests used to measure cognitive functions. In patients after SCA, the most commonly occurring disorder turned out to be 
depression, which may distort the results of tests measuring cognitive functions.

\section{Study limitations}

No methodology is perfect; in certain thematic areas, methodological compromises may even be necessary for a study to be conducted. In the case of individuals after cardiac arrest, comparing them only to healthy individuals may be misleading as SCA mainly occurs in people with heart disorders, which are frequently associated with cognitive impairment. This is why a decision was made to create another group for comparison, which was referred to as the "reference group". It was, however, not possible to create a group of SCA patients composed only of individuals after myocardial infarction, so the results should be interpreted cautiously. The small size of the group and the relatively simple set of psychological instruments may also be considered limitations. Still, the results proved to be interesting and we decided to publish our work.

\section{Practical aspects of the study}

One of the practical aspects of this study is that it emphasizes the importance of constant training of cognitive function, especially in individuals after cardiovascular episodes. This patient group should be provided with qualified care and neuropsychological rehabilitation focused on the training of cognitive functions.

\section{Conclusions}

Impairment of visual-motor skills, short-term visual memory, concentration, and visual-motor coordination occurs much more frequently and is more severe in individuals after SCA than in healthy individuals. Impairment of memory trace storage and recall after delay occurs more frequently in patients after SCA than in patients after myocardial infarction without cardiac arrest and in healthy individuals. The SCA duration did not have any influence on the severity of the described disorders.

\section{Disclosure}

Authors report no conflict of interest.

\section{References}

1. Geraghty MC, Torbey MT. Neuroimaging and serologic markers of neurologic injury after cardiac arrest. Neurol Clin 2006; 24: 107-121.
2. Kandiah P, Ortega S, Torbey MT. Biomarkers and neuroimaging of brain injury after cardiac arrest. Semin Neurol 2006; 26: 413-421.

3. Koenig MA, Kaplan PW, Thakor NV. Clinical neurophysiologic monitoring and brain injury from cardiac arrest. Neurol Clin 2006; 24: 89-106.

4. Matot I, Shleifer A, Hersch M, Lotan C, Weiniger CF, Dror Y, Einav S. In-hospital cardiac arrest: is outcome related to the time of arrest? Resuscitation 2006; 71: 56-64.

5. Weigl M, Moritz A, Steinlechner B, Schmatzer I, Mora B, Fakin R, Zimpfer D, Ankersmit HJ, Khazen C, Dworschak M. Neuronal injury after repeated brief cardiac arrests during internal cardioverter defibrillator implantation is associated with deterioration of cognitive function. Anesth Analg 2006; 103 : 403-409.

6. Krzyżanowska E, Friedman A. Zaburzenia neuropsychologiczne u pacjentów po kardiogennym niedotlenieniu mózgu. Neuropsychiatria i Neuropsychologia 2012; 7: 26-34.

7. Sauvé MJ, Walker JA, Massa SM, Winkle RA, Scheinman MM. Patterns of cognitive recovery in sudden cardiac arrest survivors: the pilot study. Heart Lung 1996; 25: 172-181.

8. Herlitz J, Castren M, Friberg H, Nolan J, Skrifvars M, Sunde K, Steen PA. Post resuscitation care: what are the therapeutic alternatives and what do we know? Resuscitation 2006; 69: 15-22.

9. Wallin E, Larsson IM, Rubertsson S, Kristofferzon ML. Cardiac arrest and hypothermia treatment: function and life satisfaction among survivors in the first 6 months. Resuscitation 2014; 85: 538-543.

10. Geocardin RG, Buitrago MM, Torbey MT, Chandra-Strobos N, Williams MA, Kaplan PW. Neurologic prognosis and withdrawal of life support after resuscitation from cardiac arrest. Neurology 2006; 67: 105-108.

11. Stetkiewicz-Lewandowicz A, Borkowska A. Badania neuropsychologiczne u pacjentów z chorobą niedokrwienną serca. Psychiatr Pol 2013; 47: 5-16.

12. Jaworowska A. Test Pamięci Wzrokowej Bentona. Polska normalizacja. Pracownia Testów Psychologicznych, Warsaw 2007.

13. Jodzio K. Neuropsychologiczna charakterystyka zaburzeń pamięci w następstwie korowych i podkorowych uszkodzeń mózgu. Psychiatr Pol 1995; 29: 491-502.

14. Jurczyński Z. Narzędzia pomiaru w psychologii zdrowia. Przegląd Psychiatryczny 1999; 42: 43-56.

15. Wieczorek D, Jodzio K, Radziwiłłowicz W. Skargi subiektywne a wyniki testów pamięci w depresji i rozlanych uszkodzeniach mózgu. Psychiatr Pol 1996; 30: 641-652.

16. Roine RO, Kajaste S, Kaste M. Neuropsychological sequelae of cardiac arrest. JAMA 1993; 269: 237-242.

17. Sauve MJ, Doolittle N, Walker JA, Paul SM, Scheinman MM. Factors associated with cognitive recovery after cardiopulmonary resuscitation. Am J Crit Care 1996; 5: 127-139.

18. Lim C, Alexander MP, LaFleche G, Schnyer DM, Verfaellie M. The neurological and cognitive sequelae of cardiac arrest. Neurology 2004; 63: 1774-1778.

19. Drysdale EE, Grubb NR, Fox KA, O'Carroll RE. Chronicity of memory impairment in long-term out-of-hospital cardiac arrest survivors. Resuscitation 2002; 47: 27-32.

20. Pusswald G, Fertl E, Faltl M, Auff E. Neurological rehabilitation of severely disabled cardiac arrest survivors. Part II: Life situation of patients and families after treatment. Resuscitation 2000; 47: 241-248.

21. Sunnerhagen KS, Johansson O, Herlitz J, Grimby G. Life after cardia arrest: a retrospective study. Resuscitation 1996; 31: 135-140.

22. Polanowska KE, Sarzyńska-Długosz IM, Paprot AE, Sikorska S, Seniów JB, Karpiński G, Kowalik R, Opolski G, Członkowska A. Neuropsychological and neurological sequelae of out-of-hospital cardiac arrest and estimated need for neurorehabilitation: a prospective pilot study. Kardiol Pol 2014; 72: 814-822. 